\title{
PENGASAPAN IKAN KEMBUNG MENGGUNAKAN ASAP CAIR DARI KAYU KARET HASIL REDESTILASI
}

\author{
Erdi Suroso ${ }^{\star}$, Tanto Pratondo Utomo, Sri Hidayati, Astri Nuraini \\ Jurusan Teknologi Hasil Pertanian Fakultas Pertanian Universitas Lampung \\ Jalan Prof. Soemantri Brojonegoro No. 1 Bandar Lampung, Lampung, 35145, Telepon. (0721) 704946. \\ Korespondensi: erdi.suroso@fp.unila.ac.id \\ Diterima: 18 Januari 2018/ Disetujui: 29 Maret 2018
}

Cara sitasi: Suroso E, Utomo TP, Hidayati S, Nuraini A. 2018. Pengasapan ikan kembung menggunakan asap cair dari kayu karet hasil redestilasi. Jurnal Pengolahan Hasil Perikanan Indonesia. 21(1): 42-53.

\begin{abstract}
Abstrak
Asap cair dari kayu karet dapat digunakan sebagai bahan pengawet ikan kembung (Rastrelliger kanagurta) karena mengandung senyawa fenol dan asam organik yang bersifat sebagai senyawa anti bakteri dan antioksidan. Penelitian ini bertujuan untuk menentukan konsentrasi asap cair kayu karet redestilasi dan lama perendaman ikan terbaik pada pengasapan ikan kembung. Penelitian menggunakan rancangan acak kelompok faktorial (RAK Faktorial) dengan perlakuan konsentrasi asap cair (10, 15 dan 20\%) dan lama perendaman (10, 15 dan 20 menit). Analisis meliputi angka lempeng total, kadar air dan organoleptik. Hasil terbaik yaitu menggunakan konsentrasi asap cair kayu karet redestilasi $10 \%$ dan lama perendaman ikan selama 15 menit dengan nilai angka lempeng total $4,4 \times 10^{3} \mathrm{CFU} / \mathrm{g}$ pada hari ke- 0 dan $4,7 \times 10^{4} \mathrm{CFU} / \mathrm{g}$ pada hari ke-6, kadar air di bawah $60 \%$ selama penyimpanan, dan sifat organoleptik berupa skor aroma 4,48 (netral) dan skor penerimaan keseluruhan 4,51 (netral).
\end{abstract}

Kata kunci: asap cair, ikan kembung, kayu karet, pengasapan, redestilasi

\section{Fumigation of Mackerel using Liquid Smoke from Redestillated Rubber Wood}

Abstract
Liquid smoke from rubber wood can be used as a preservative of bloated fish (Rastrelliger kanagurta) because it contains compounds of phenols and organic acids that are as antibacterial and antioxidant compounds. This study aimed to obtain the concentration of liquid smoke of redestillated rubber wood and the immersion period of fumigation to produce the best smoked fish. The treatment was carried out factorially in a complete randomized group design with treatment of liquid smoke consentrations (10, 15 and $20 \%)$ and soaking time (10, 15 and $20 \mathrm{~min})$. The parameters analyzed were total plate count, moistureand organoleptics. The best result was the use of liquid smoke at $10 \%(\mathrm{v} / \mathrm{v})$ redox- and fish immersion duration for 15 minutes with total plate values of $4.4 \times 10^{3} \mathrm{CFU} / \mathrm{g}$ on day 0 and $4.7 \times 10^{4} \mathrm{CFU} / \mathrm{g}$ on day 6 , moisture content below $60 \%$ during storage, and organoleptic properties in term of aroma was 4.48 (neutral) and overall acceptance score was 4.51 (neutral).

Keywords: curing, liquid smoke, mackerel, redestillation, rubber wood

\section{PENDAHULUAN}

Pengawetan ikan kembung dapat dilakukan dengan menggunakan garam (Desniar et al. 2009), penggunaan ekstrak etanol rumput laut Padina sp. (Husni et al. 2015), serta pengasapan (Dwiyitno dan Riyanto 2006). Pengasapan merupakan salah satu metode yang digunakan untuk mengawetkan produk makanan yang mengandung protein tinggi misalnya ikan, daging dan keju. Produk pangan dengan proses pengasapan memiliki kelebihan daya awet yang tinggi, rasa dan aroma yang ditimbulkan juga sangat sangat khas. Daya awet yang ditimbulkan dari komponen asap cair karena adanya kandungan yang bersifat antimikrobial dan antioksidan yaitu senyawa aldehid, asam karboksilat dan fenol (Leroi dan Joffraud 2000; Rorvik 2000).

Pengasapan menggunakan cara tradisional dengan cara pembakaran langsung, memiliki beberapa kelemahan, yaitu kualitas 
produk yang dihasilkan tidak konsisten, terakumulasinya senyawa berbahaya misalnya tar dan benzopiren pada produk, selain itu juga menyebabkan pencemaran udara, serta efisiensi pengasapan sulit dikontrol. Metode untuk mengurangi kelemahan tersebut dilakukan dengan cara menggunakan asap cair. Pengasapan asap cair memiliki kelebihan yaitumudah diterapkan, flavor produk lebih seragam, lebih efisien dalam penggunaan bahan pengasap dan senyawa karsinogenik berupa senyawa aromatik polisiklik yang terbentuk dapat dieliminasi (Simon et al. 2005; Hattula et al. 2001). Aplikasi asap cair sebagai antimikroba sudah dilaporkan pada berbagai produk (Sunen et al. 2001; Milly et al. 2005), yaitu pada ikan salmon (Stohr et al. 2001; Kolodziejska et al. 2002; Montero et al. 2003; Martinez et al. 2011), ikan todak (Muratore dan Licciardello 2005), ikan pari (Dayatis blekeery)(Swastawati et al. 2012) dan berbagai jenis ikan (Jittinandana et al. 2003; Sunen et al. 2003). Aktivitas antimikroba dan sifat sensoris dari asap cair yang dihasilkan dari proses redestilasi dengan bahan baku kayu karet terutama aplikasinya pada ikan kembung hanya sedikit diinformasi.

Kayu karet terutama yang telah berusia tua memiliki kandungan lignoselulosa yang terdiri atas heloselulosa $70 \%$, selulosa $40 \%$, hemiselulosa 20\%, lignin 20,68\%, dan ekstraktif 4,58\% (Boerhendhy 2006). Golongan senyawa pada asap cair kayu oak antara lain aldehid, keton, diketon, ester, alkohol, asam, turunan furan and piran, siringol, guaiakol, derivat fenol and pirokatekol,alkil dan aril eter, serta turunan furan dan piran (Guillén dan Manzanos 2002). Proses pembakaran kayu akan menghasilkan asap yang mempunyai aktivitas antibakteri yang superior (Braithwaite et al. 2008). Suñen et al. (2003)menyatakan bahwa efek antimikroba dari kondensat asap kayu pada mikrobapathogen Listeriamonocytogenes dan Aeromonas hydrophila.

Asap cair memiliki komponen utamayang terdiri dari 1,2-asam benzendikarboksilat dan dietil 5 ester(Sari etal.2007). Asap cair darikayu jati, lamtorogung, mahoni, kamper, bangkirai, keruing dan batang kelapa menghasilkan asam (sebagai asam asetat) berkisar antara $4,27-11,30 \%$, senyawa fenolat (sebagai fenol) $2,10-5,13 \%$ dan senyawa karbonil (sebagai aseton) 8,56-15,23\% sedangkan Karseno et al. (2010) melaporkan bahwa asap cair dari karet terdeteksi mengandung komponen senyawa fenol yaitu kresol dan guaiakol serta asam (asetat dan propionat). Asap cair kayu karet memiliki nilai $\mathrm{pH}$ 2,8 dan kandungan asam 5,18\%. Asap cair kayu karet mengandung fenol 2,10 \% (Towaha et al. 2013).

Ikan kembung (Rastrelliger kanagurta) merupakan jenis ikan laut yang disukai oleh masyarakatkarena kandungan gizinya, mudah diperoleh dan memiliki rasa yang lezat (Siregar 2011), dengan nilai preferensi pada rumah tangga nasional yaitu 6,91\% (BPS 2014). Ikan kembung mengandung protein $22 \%$ dan kandungan asam lemak omega-3 $70 \%$ dari total lemak yang ada di dalam ikan kembung (Effendie 2002).

Ikan kembung akan membusuk dalam waktu 12-20 jam pada kondisi suhu tropik, tergantung alat atau cara penangkapan dan proses penanganan pasca penangkapan (Siregar 2011). Penelitian ini bertujuan untuk menentukankonsentrasi asap cair dan lama perendaman menggunakan asap cair kayu karet redestilasi terhadap sifat anti bakteri dan organoleptik ikan kembung.

\section{BAHAN DAN METODE Bahan dan Alat}

Bahan-bahan yang digunakan dalam penelitian ini adalah ikan kembung yang dibeli di Gudang Lelang Ikan, Bandar Lampung dengan ukuran perekor berkisar 200 gram, kayu karet, zeolit, akuades, asap cair grade 2 dan grade 3, larutan $\mathrm{HCl} \mathrm{1,2} \mathrm{M} \mathrm{(Merck),}$ media PCA (Oxoid) dan $\mathrm{NaCl}$ (Oxoid).

Seperangkat alat pirolisis produksi (Gama Mesin Mandiri, Indonesia), timbangan analitik (Shimadzu AV 220, Jepang), alat gelas (Pyrex, USA), alat destilasi (Gama Mesin Mandiri, Indonesia), inkubator (Pyrex Iwaki, USA), colony counter (suntex 570 USA), hot plate (E- Scientific,USA), oven (Memmert, Jerman), kertas saring, Gas CromatographyMass Spectrometer (Varian/CP-3800 GC dan Saturn 2200 MS, USA). 


\section{Metode Penelitian}

Asap cair yang digunakan pada penelitian ini dihasilkan dari proses pirolisis pada suhu $400^{\circ} \mathrm{C}$ (Satyajaya et al. 2016). Asap cair yang dihasilkan selanjutnya dilakukan pemisahan tar dalam dua tahap sehingga dihasilkan asap cair grade 3 (Utomo 2014). Asap cair grade 3 ini selanjutnya dimurnikan menggunakan metode destilasi dan penyaringan dengan zeolit aktif sehingga dihasilkan asap cair grade 2 (Lestari et al. 2015).

Asap cair grade 2 yang dihasilkan selanjutnya diencerkan menggunakan akuades hingga konsentrasi 10\% (v/v), $15 \%$ $(\mathrm{v} / \mathrm{v})$, dan $20 \%(\mathrm{v} / \mathrm{v})$ sebelum diaplikasikan ke ikan kembung. Ikan kembung yang digunakan merupakan ikan kembung yang telah dibersihkan terlebih dahulu kemudian direndam dalam larutan garam $10 \%(\mathrm{~b} / \mathrm{v})$ (Yanti dan Rochima 2009). Ikan kembung selanjutnya direndam dalam masing-masing asap cair dengan konsentrasi 10\% (v/v), 15\% (v/v) dan 20\% (v/v) selama 10 menit, 15 menit dan 20 menit.

\section{Prosedur Analisis}

Identifikasi komponen kimia asap cair kayu karet berupa identifikasi komponen kimia dengan menggunakan alat GC-MS Kualitatif. Angka lempeng total ikan kembung asap mengacu pada (BSN 2015). Pengukuran kadar air yang dilakukan pada ikan kembung mengacu pada metode (AOAC 2007). Sifat organoleptik (aroma, tekstur, warna, kenampakan dan penerimaan keseluruhan) mengacu pada (Kartika dan Bambang 1988). Analisis kandungan logam berat dilakukan sesuai dengan metode AOAC (2005) dengan cara mendestruksi sampel menggunakan asam kuat sehingga logam dalam keadaan terlarut. Analisis logam berat terdiri dari logam merkuri $(\mathrm{Hg})$, timbal $(\mathrm{Pb})$ dan cadmium (Cd)dilakukan dengan menggunakan AAS (Atomic Absorbtion Spectrofotometer).

\section{Analisis Data}

Penelitian disusun secara faktorial dalam Rancangan Acak Kelompok Lengkap (RAKL) dengan dua faktor dan tiga kali ulangan, data yang diperoleh diuji kesamaan ragamnya dengan uji Bartlett dan keaditifitasan dengan uji Tuckey. Analisis sidik ragam digunakan untuk mengetahui ada tidaknya pengaruh perlakuan, kemudian dilakukan uji lanjut menakngguan uji Duncan Multiple Range Test pada taraf $5 \%$.

\section{HASIL DAN PEMBAHASAN Komponen Kimia}

Hasil analisis Gas Chromatography-Mass Spectroscopy (GC-MS) pada asap cair kayu karet grade 3 menghasilkan senyawa-senyawa golongan guaiakol diikuti oleh senyawasenyawa golongan fenol, asam organik, keton, furan, siringol, dan alkil aril eter (Tabel 1) sedangkan asap cair kayu karet grade 2 mengandung senyawa asam organik dan senyawa-senyawa golongan fenol, guaiakol, keton, siringol, alkil aril eter dan furan (Tabel 1). Senyawa hidrokarbon poli aromatik (HPA) termasuk senyawa benzo (a) piren tidak ditemukan pada asap cair kayu karet. Stolyhwo dan Sikorski (2005) melaporkan bahwa suhu pemanasan, penggunaan suhu pirolisis antara $300-400^{\circ} \mathrm{C}$ dapat menurunkan kandungan HPA dalam

Tabel 1 Komponen kimia asap cair kayu karet grade 3 berdasarkan hasil analisis

Gas Chromatography Mass Spectroscopy (GC-MS)

(Table 1 Chemical components of grade 3 rubber liquids smoke based on Chromatography Mass Spectroscopy (GC-MS) analysis)

\begin{tabular}{cccccc}
\hline \multirow{2}{*}{ No } & \multirow{2}{*}{ Component } & \multicolumn{2}{c}{ Retention time (minute) } & \multicolumn{2}{c}{ Area (\%) } \\
& & Grade 3 & Grade 2 & Grade 3 & Grade 2 \\
\hline \multicolumn{2}{c}{ Acid and Carbonyl } & & & & \\
1 & Acetic acid, methyl ester & 1.970 & & 1.344 & \\
2 & Acetic acid, anhydride (CAS) & 2.308 & 2.357 & 7.335 & 50.879 \\
3 & Acetic acid (CAS) & 2.381 & 2.435 & 0.118 & 0.188
\end{tabular}




\begin{tabular}{rrcc}
4 & Acetic acid, ethyl ester & 2.764 & 0.354 \\
5 & Ethanedioic acid, dibutyl ester & 2.950 & 7.783 \\
6 & Benzoic acid, methyl ester (CAS) & 15.485 & 0.394 \\
\hline
\end{tabular}

\begin{tabular}{|c|c|c|c|c|c|}
\hline \multicolumn{6}{|c|}{ Ketones } \\
\hline 7 & 2,4-Diacetoxypentane & 2.701 & & 0.268 & \\
\hline 8 & 3-Acetoxy-1,2,4-trioxolane & 2.815 & & 1.724 & \\
\hline 9 & Pentane,3-methyl- (CAS) & 2.975 & & 2.109 & \\
\hline 10 & Cyclohexanone & 5.120 & & 0.482 & \\
\hline 11 & $\begin{array}{c}\text { 2-Cyclopenten-1-one,2-methyl- } \\
\text { (CAS) }\end{array}$ & 8.922 & 11.165 & 1.369 & 0.904 \\
\hline 12 & 2-Cyclopenten-1-one,2,3-dimethyl & 12.224 & & 0.849 & \\
\hline 13 & $\begin{array}{c}\text { 2-Cyclopenten-1-one,3-(1- } \\
\text { methylethyl)-(CAS) }\end{array}$ & 15.674 & & 0.835 & \\
\hline 14 & Acetonyl decyl ether & & 3.090 & & 2.574 \\
\hline 15 & $\begin{array}{c}\text { 2-Cyclopenten-1-one,2-hydoxy-3- } \\
\text { methyl }\end{array}$ & & 13.199 & & 0.708 \\
\hline 16 & 5-Hydroxy-2-heptanone & & 13.628 & & 0.316 \\
\hline 17 & $\begin{array}{c}\text { Cyclopentasiloxane, decamethyl- } \\
\text { (CAS) }\end{array}$ & & 16.628 & & 0.453 \\
\hline \multicolumn{6}{|c|}{ Furan } \\
\hline 18 & 2-Furancarboxaldehyde (CAS) & 6.364 & 6.390 & 4.637 & 0.308 \\
\hline 19 & $\begin{array}{l}\text { 2-Furancarboxaldehyde,5-methyl- } \\
\text { (CAS) }\end{array}$ & 10.984 & & 1.690 & \\
\hline 20 & $\begin{array}{c}\text { 2-Furancarboxylic acid,methyl } \\
\text { ester (CAS) }\end{array}$ & 11.425 & & 0.587 & \\
\hline 21 & $\begin{array}{l}\text { 2-Furanone,2,5-dihydro-3,5- } \\
\text { dimethyl }\end{array}$ & & 12.284 & & 0.538 \\
\hline \multicolumn{6}{|c|}{ Phenol } \\
\hline 22 & Phenol (CAS) & 11.599 & 11.590 & 1.744 & 3.575 \\
\hline 23 & Phenol,2-methyl-(CAS) & 14.156 & 14.148 & 2.814 & 0.960 \\
\hline 24 & Phenol,4-methyl-(CAS) & 14.895 & 14.889 & 3.649 & 4.292 \\
\hline 25 & Benzofuran,2,3-dihydro & 15.068 & & 0.324 & \\
\hline 26 & Phenol,2,5-dimethyl-(CAS) & 15.953 & & 1.061 & \\
\hline 27 & Phenol,2-ethyl-(CAS) & 16.852 & & 0.866 & \\
\hline 28 & Phenol,2,4-dimethyl-(CAS) & 17.226 & 17.228 & 2.115 & 0.501 \\
\hline 29 & Phenol,2,3-dimethyl-(CAS) & 17.296 & 17.300 & 1.432 & 0.358 \\
\hline 30 & Phenol,4-ethyl-(CAS) & 17.778 & 17.786 & 0.612 & 0.365 \\
\hline 31 & Phenol,3-ethyl-(CAS) & 17.832 & 17.834 & 0.674 & 0.406 \\
\hline 32 & Phenol,3,5-dimethyl-(CAS) & 17.895 & 17.891 & 0.551 & 0.375 \\
\hline 33 & Phenol,3,4-dimethyl-(CAS) & 18.621 & 18.619 & 0.065 & 1.024 \\
\hline 34 & Phenol,2,4,6-trimetyl- & 19.001 & 19.012 & 0.773 & 0.196 \\
\hline 35 & Phenol,2-ethyl-6-methyl & 19.594 & & 0.579 & \\
\hline 36 & Phenol,2-ethyl-5-methyl & 19.746 & & 0.244 & \\
\hline
\end{tabular}




\begin{tabular}{|c|c|c|c|c|c|}
\hline 37 & Phenol,2,3,6-trimethyl & 19.812 & & 0.341 & \\
\hline 38 & Phenol,2,3,5-trimethyl & 20.060 & & 0.303 & \\
\hline 39 & Phenol,3-ethyl-5-methyl & 20.544 & & 1.050 & \\
\hline 40 & Phenol-2-ethyl-6-methyl & 20.805 & & 0.517 & \\
\hline \multicolumn{6}{|c|}{ Guaiakol } \\
\hline 41 & Phenol,2-methoxy-(CAS) & 15.277 & 15.274 & 8.090 & 2.561 \\
\hline 42 & Phenol,2-methoxy-3-methyl-(CAS) & 18.126 & 18.129 & 2.266 & 0.445 \\
\hline 43 & Phenol,4-methoxy-3-methyl-(CAS) & 18.404 & & 1.292 & \\
\hline 44 & Phenol,4-ethyl-2-methoxy-(CAS) & 21.022 & 21.022 & 11.243 & 3.088 \\
\hline 45 & Phenol,2-methoxy-4-(1-propenyl)- & 24.579 & & 0.271 & \\
\hline 46 & Phenol,2-methoxy-4-methyl & & 18.540 & & 2.380 \\
\hline \multicolumn{6}{|c|}{ Siringol } \\
\hline 47 & Phenol,2,6-dimethoxy- (CAS) & 23.061 & 23.061 & 0.366 & 2.373 \\
\hline 48 & $\begin{array}{c}\text { Phenol,2-methoxy-6-(2-propenyl)- } \\
\text { (CAS) }\end{array}$ & 23.194 & 23.201 & 1.446 & 0.723 \\
\hline 49 & $\begin{array}{l}\text { Phenol,2-methoxy-4-ethyl-6- } \\
\text { methyl }\end{array}$ & 23.259 & & 0.505 & \\
\hline 50 & $\begin{array}{c}\text { Phenol,2-methoxy-4-propyl- } \\
\text { (CAS) }\end{array}$ & 23.464 & 23.464 & 2.046 & 0.594 \\
\hline 51 & $\begin{array}{c}\text { Phenol,2-methoxy-6-(2-propenyl)- } \\
\text { (CAS) }\end{array}$ & & 23.201 & & 0.723 \\
\hline \multicolumn{6}{|c|}{ Alkyl aryl ether } \\
\hline 52 & Benzene,1,2-dimethoxy-(CAS) & 17.139 & & 0.247 & \\
\hline 53 & 2,3-dimethoxytoluene & 19.915 & 19.913 & 1.825 & 0.538 \\
\hline 54 & Benzene,4-ethyl-1,2-dimethoxy- & 22.265 & & 0.227 & \\
\hline 55 & $\begin{array}{c}\text { Benzene,1,2,3-trimethoxy-5- } \\
\text { methyl-(CAS) }\end{array}$ & 24.346 & 24.346 & & 0.671 \\
\hline
\end{tabular}

asap cair hingga 10 kali lipat. Komponen utama dalam asap cair yaitu asam karbiksiolat, fenol dan karbonil. Degradasi hemiselulosa menghasilkan furan, furfural dan asam asetat (Achmadi et al. 2013).

Hasil identifikasi komponen kimia menunjukkan asap cair kayu karet grade 2 dapat digunakan sebagai bahan pengawet panganyang aman untuk dikonsumsi karena tidak ditemukannya kandungan senyawa berbahaya misalnya tar dan senyawa HPA. Proses pirolisis dari lignin menghasilkan fenol yang memberikan kontribusi terhadap aroma dan warna serta berfungsi sebagai bakteristatik (Sengul et al. 2009). Asam organik yang dihasilkan pada proses pirolisis berfungsi sebagai penghambat pertumbuhan bakteri (Esekhiagbe et al. 2009). Menurut Suroso et al. (2017), asap cair dalam sektor pangan dapat digunakan sebagai pengawet pada jenis makanan seperti ikan, daging, dan mie.

\section{Angka Lempeng Total}

Hasil analisis sidik ragam menunjukkan bahwa konsentrasi asap cair berpengaruh nyata terhadap nilai angka lempeng total (ALT) ikan kembung asap selama 6 hari masa penyimpanan. Lama perendaman ikan berpengaruh nyata terhadap nilai ALT ikan kembung asap pada hari ke-0 dan 6 tetapi tidak berpengaruh nyata pada hari ke-3. Interaksi antara konsentrasi asap cair dan lama perendaman tidak berpengaruh nyata 


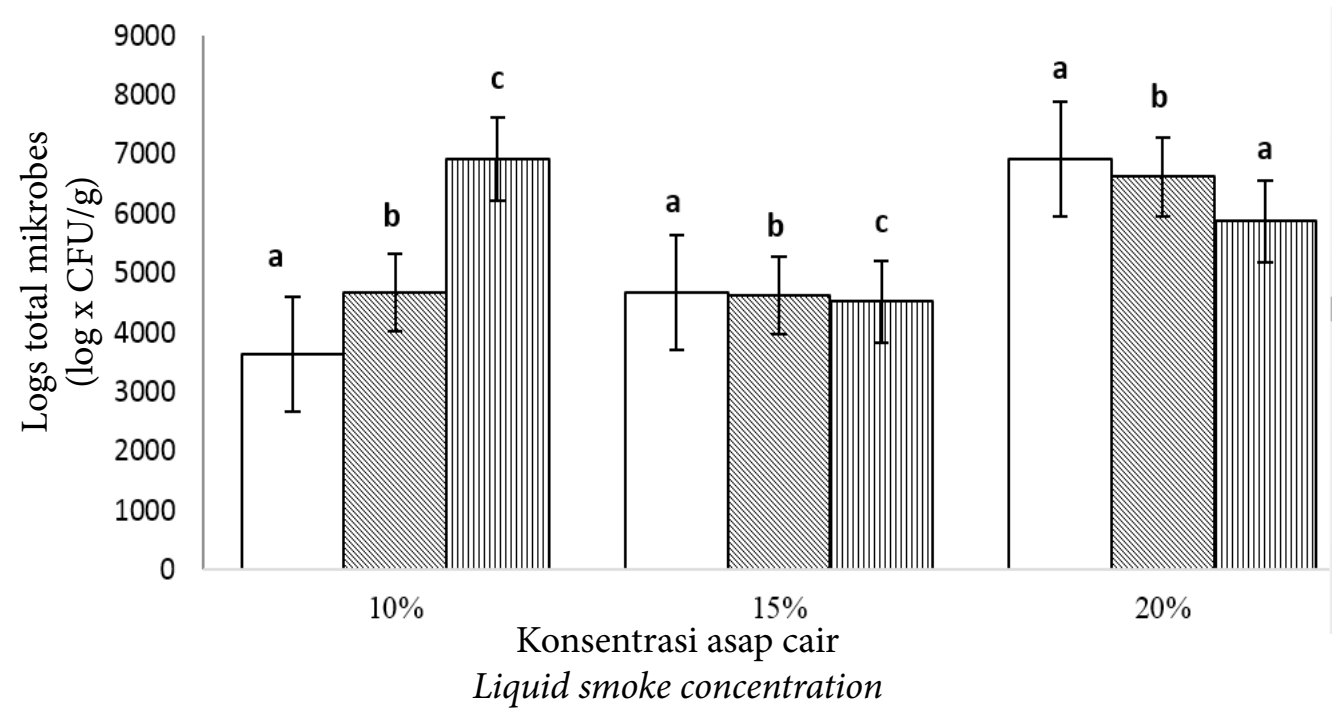

Gambar 2 Angka lempeng total ikan kembung asap selama penyimpanan. Penyimpanan hari

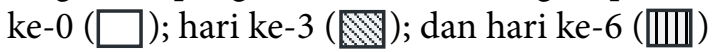

(Figure 2 Total plate count of smoked R. kanagurta during storage. Storage day-0 ( $\square$ ); day-3

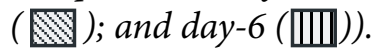

terhadap nilai ALT ikan kembung asap selama 6 hari masa penyimpanan (Gambar 2).

Konsentrasi asap cair $20 \%(\mathrm{v} / \mathrm{v})$ dan faktor lama perendaman 20 menit memiliki nilai ALT yang paling rendah. Beberapa komponen asap cair dilaporkan memiliki aktivitas fungsional. Bortolomeazzi et al. (2007) menyatakan bahwa asap cairmemiliki aktivitas antioksidan dan antibakteri di antaranya dihidroksi-benzen,2,6-dimetoksifenol dan 2-metoksifenol.Konsentrasi asap cair yang semakin tinggi dan waktu perendaman ikan yang semakin lama menyebabkan komponen asap cair yang berdifusi ke dalam ikan semakin banyak sehingga efek antimikrobial asap cair pada ikan kembungsemakin tinggi. Komponen fenolikmisalnya feno 1, 2-methoxylphenol (guaiacol), 3,4 dimethoxylphenols dan 2-methoxy-4methylphenol merupakan komponen dominan yang memiliki sifat anti bakterial (Vitt et al. 2001; Sunen et al. 2001; Sunen et al. 2003; Muratore dan Licciardello 2005; Milly et al. 2005; Gomez-Estaca et al. 2007; Kristinsson et al. 2007; Soldera et al. 2008). Fenol menyerang sel vegetatif, berpenetrasi dan mempresipitasi protein di dalam sel mikrona (Panagan dan syarif 2009). Penghambatan oleh fenol juga disebabkan adanya interaksi antara ikatan hidrogen dengan protein penyusun enzim (Saravanakumar et al. 2009). Komponen asam di antaranya asam asetat juga bertindak sebagai antibakterial (Budijanto et al. 2008) sehingga dapat menurunkan jumlah ALT.

Nilai ALT ikan kembung asap mengalami peningkatan selama 6 hari masa simpan, bahkan permukaan ikan kembung asap sudah ditumbuhi oleh kapang pada pengamatan hari ke-6. Penyimpanan ikan kembung asap di dalam wadah di suhu ruang diduga menjadi penyebab tumbuhnya kapang. Kapang umumnya bersifat mesofilik, yaitu tumbuh baik pada suhu kamar antara $25-35^{\circ} \mathrm{C}$, sehingga penyimpanan bahan pangan pada suhu kamar rentan ditumbuhi oleh kapang (Waluyo 2007).

\section{Kadar Air}

Hasil analisis sidik ragam kadar air ikan kembung asap menunjukkan bahwa konsentrasi asap cair tidak berpengaruh nyata terhadap kadar air ikan kembung asap selama penyimpanan tetapi lama perendaman ikan berpengaruh nyata terhadap kadar air ikan kembung asap. Interaksi antara konsentrasi asap cair dan lama perendamantidak 


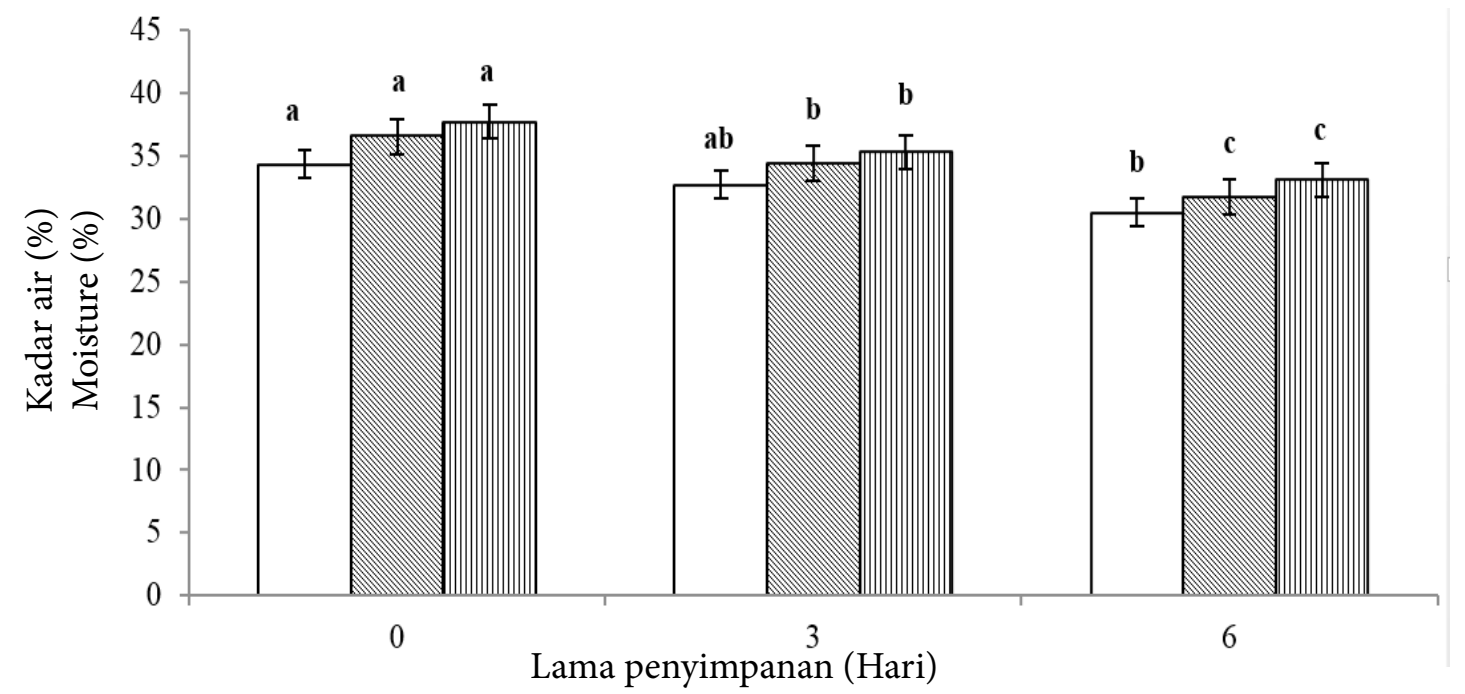

Gambar 3 Kadar air ikan kembung asap selama penyimpanan. Penyimpanan

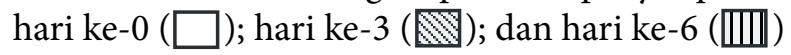

(Figure 3 Moisture content of smoked R. kanagurta during storage. Storage day-0 ( $\square$ ); storage day-3 (ख); and day-6 (四)).

berpengaruh nyata terhadap kadar air ikan kembung asap selama penyimpanan. Histogram kadar air ikan kembung asap terhadap faktor lama perendaman disajikan pada Gambar 3.

Hasil uji lanjut menunjukkan semakin lama perendaman ikan didalam asap cair maka kadar airsemakin rendah. Setha (2011) melaporkan bahwa kadar air daging ikan yang direndam dalam larutan asap cair akan mengalami penurunan akibat proses osmosis. Jumlah air bebas yang terdapat dalam daging ikan akan semakin berkurang akibat masuknya komponen asap.

Kadar airikan kembung meningkat selama 6 hari masa penyimpanan yang disebabkan karena kelembaban udara sekitar lebih tinggi dibandingkan dengan kadar air ikan kembung asap pada penyimpanan suhu kamar. Menurut Winarno (2004), apabila kadar air bahan rendah sedangkan kelembaban disekitarnya tinggi maka akan terjadi penyerapan uap air dari udara sehingga bahan menjadi lembab. Kadar air yang mengalami peningkatan juga dapat disebabkan oleh meningkatnya nilai ALT ikan kembung asap selama penyimpanan. Himawati (2010) menyatakan bahwa kadar air ikan asap meningkat disebabkan adanya aktivitas mikroba pada ikan yang akan menghasilkan air selama melakukan proses metabolisme.

\section{Sifat Organoleptik Aroma}

Hasil analisis sidik ragam menunjukkan konsentrasi asap cair dan lama perendaman berpengaruh nyata terhadap aroma ikan kembung selama penyimpananInteraksi antara perlakuan konsentrasi asap cair dan lama perendaman berpengaruh nyata terhadap aroma ikan kembung asap pada pengamatan hari ke-0 dan 3 tetapi interaksi tidak berpengaruh nyata pada pengamatan hari ke-6 (Gambar 4).

Skor aroma ikan kembung asap mengalami penurunan selama penyimpanan. Penurunan skor aroma tersebut dapat disebabkan oleh meningkatnya nilai ALT yang mengindikasikan mulai tumbuhnya mikroba yang tidak diinginkan pada ikan kembung asap. Rahayu et al. (1992) menyatakan bahwa penyimpangan aroma yang terjadi pada produk perikanan disebabkan oleh aktivitas mikroorganisme dan adanya enzim. Bau busuk terjadi akibat aktivitas bakteri proteolitik yang memecah protein menjadi senyawa-senyawa sederhana yang berbau tidak sedap di antaranyaamomonia, $\mathrm{H}_{2} \mathrm{~S}$, indol dan skatol sedangkan bau tengik disebabkan 


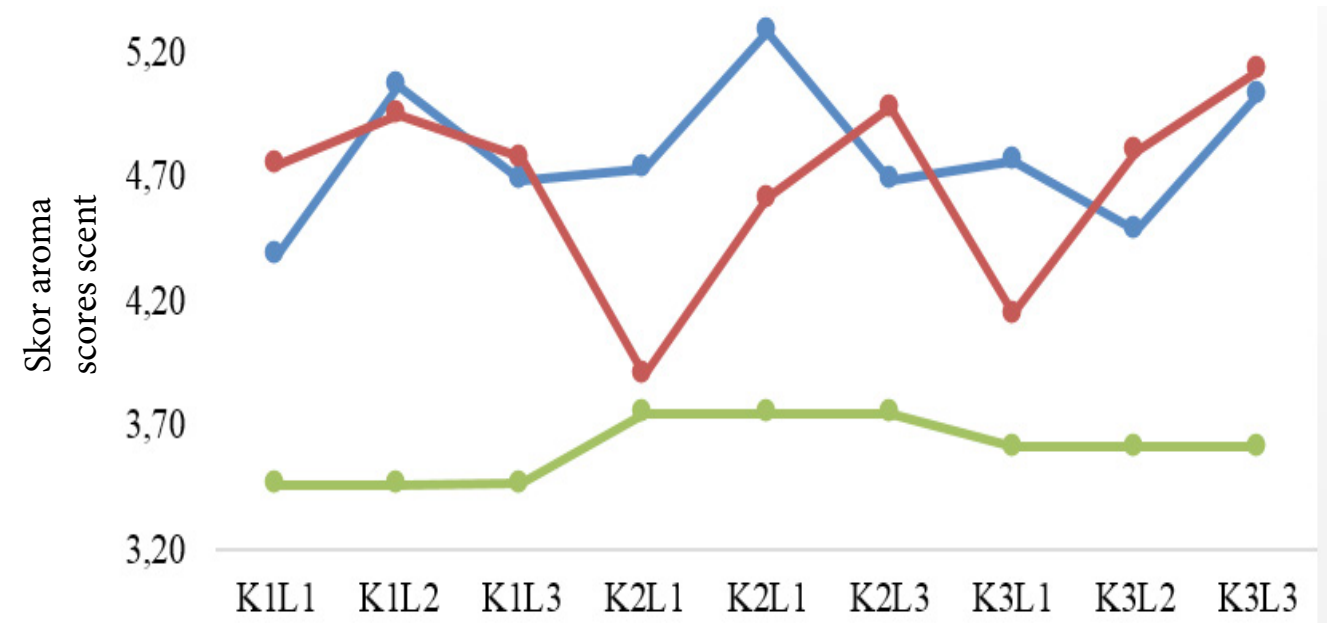

Gambar 4 Aroma ikan kembung asap selama penyimpanan. Penyimpanan hari ke-0 ( $\longrightarrow$ ); hari ke-3 ( $\longrightarrow$ ); dan hari ke-6 $(\longrightarrow)$.

(Figure 4 Aroma of smoked R. kanagurta during storage. Storage day-0 (—); storage day-3 $(\longrightarrow)$; and day- $6(\longrightarrow)$ ).

oleh reaksi enzim lipolitik dan oksigen (Achmadi et al. 2013).

Senyawa golongan fenol pada asap cair merupakan senyawa utama pemberi aroma pada ikan asap dan mampu memberikan aroma pungent, eresoline, manis asap, dan seperti bau terbakar (Hadiwiyoto et al. 2000; Cardinal et al. 2006. Konsentrasi dan lama penyimpanan yang semakin meningkat tidak memberikan hasil penerimaan yang lebih baik. Hasil penelitian menunjukkan bahwa panelis cenderung menyukai ikan kembung asap dengan konsentrasi asap cair $15 \%$ yang direndam selama15 menit dibandingkan dengan konsentrasi asap cair $20 \%$ dan lama perendaman 20 menit. Swastawati et al. (2012) juga melaporkan bahwa semakin lama penyimpanan maka penerimaan terhadap aroma ikan pari asap dari asap cair tongkol jagung dan sabut kelapa akan semakin menurun.

\section{Penerimaan Keseluruhan}

Hasil analisis sidik ragam menunjukkan konsentrasi asap cair tidak berpengaruh nyata terhadap penerimaan keseluruhan ikan kembung asap selama 6 hari masa penyimpanan, sedangkan lama perendaman berpengaruh nyata terhadap penerimaan keseluruhan ikan kembung asap pada pengamatan harike-3 tetapi tidak berpengaruh nyata pada pengamatan hari ke-0 dan 6 . Interaksi antara perlakuan konsentrasi asap cair dan lama perendaman berpengaruh nyata terhadap penerimaan keseluruhan ikan kembung asap padapengamatn hari ke-3 dan 6 tetapi tidak berpengaruh nyata pada pengamatan hari ke-0 (Gambar 5).

Menurut De Fretes et al. (2015), semakin tinggi konsentrasi asap cair dan semakin lama perendaman ikan maka semakin banyak senyawa dalam asap cair yang diserap sehingga akan meningkatkan penerimaan panelis. Daya terima panelis terhadap sifat organoleptik ikan asap secara umum menjadi lebih tinggi karena selama pengovenan produk akan menjadi lebih awet, warna, aroma dan rasa menjadi lebih baik. Menurut Hadiwiyoto et al. (2000), warna cokelat pada ikan asap timbul sebagai adanya interaksi senyawa karbonil dalam asap cair dengan senyawa amino dalam daging ikan, senyawa fenol juga turut memberikan warna cokelat pada produk ikan asap. Senyawa fenol meleleh pada lemak yang ada pada bagian kulit luar ikan dan mengendalikan oksidasi langsung pada bagian berlemak sehingga mencegah terjadinya perubahan warna kemerahan pada produk akhir (Sulistijowati 2011). Skor penerimaan keseluruhan mengalami 


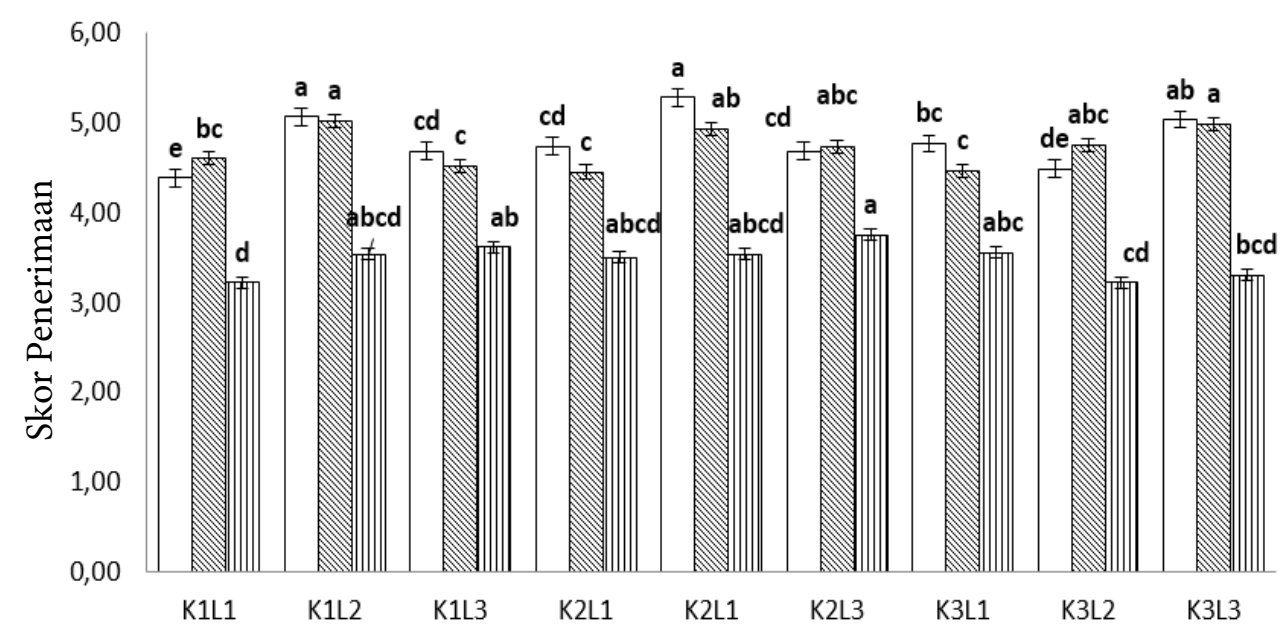

Gambar 5 Nilaipenerimaan keseluruhan ikan kembung asap selama penyimpanan. Penyimpanan

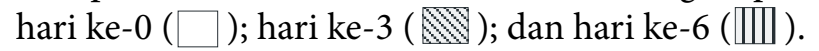

(Figure 5 Overall acceptance of smoked R. kanagurta during storage. Storage day-0 ( $\square$ ); storage day-3 (ख); and day- 6 ( [III)).

penurunan selama penyimpanan disebabkan oleh aroma tengik yang mulai muncul, serta kenampakan ikan kembung asap yang mulai ditumbuhi oleh kapang. Menurut Nur (2009), meningkatnya kadar air dan jumlah mikroba dapat menurunkan tingkat penerimaan terhadap aroma, tekstur, dan kenampakan produk dan secara tidak langsung akan menurunkan skor penerimaan keseluruhan produk.

Perlakuan terbaik pada penelitian ini ditentukan berdasarkan pengamatan utama, yaitu angka lempeng total (ALT), kadar air, dan uji organoleptik (aroma, tekstur, warna, kenampakan dan penerimaan keseluruhan) yang dilakukan terhadap ikan kembung asap. Kriteria ikan asap yang baik adalah memiliki kadar air maksimum $60 \%$ fraksi massa (BSN 2009), nilai ALT maksimum $1,0 \times 10^{5} \mathrm{CFU} / \mathrm{g}$ (BSN 2009) dan skor organoleptik normal (4.00).

Hasil penelitian menunjukkan kadar air ikan kembung asap memenuhi persyaratan SNI selama 6 hari masa simpan, yaitu di bawah $60 \%$. Nilai ALT ikan kembung asap memenuhi persyaratan SNI pada pengamatan hari ke-0 dan ke-3 tetapi sudah tidak memenuhi persyaratan SNI pada pengamatan hari ke-6. Hasil pengujian organoleptik menunjukkan perlakuan K1L2 paling banyak memenuhi persyaratan skor organoleptik untuk parameter aroma, tekstur, warna, kenampakan, dan penerimaan keseluruhan selama 6 hari masa simpan. Berdasarkan hal tersebut dipilih perlakuan terbaik yaitu penggunaan konsentrasi asap cair kayu karet redestilasi 10\% (v/v) (K1) dan lama perendaman ikan dalam asap cair kayu karet redestilasi selama 15 menit (L2) dengan nilai angka lempeng total $4,4 \times 10^{3} \mathrm{CFU} / \mathrm{g}$ pada hari ke-0 dan $4,7 \times 10^{4} \mathrm{CFU} / g$ pada hari ke-6, kadar air di bawah $60 \%$ selama penyimpanan, dan sifat organoleptik berupa skor aroma 4,48 (netral) dan skor penerimaan keseluruhan 4,51 (netral).

\section{KESIMPULAN}

Perlakuan terbaik adalah dengan konsentrasi asap cair kayu karet redestilasi $10 \%(\mathrm{v} / \mathrm{v})(\mathrm{K} 1)$ dan lama perendaman ikan selama 15 menit (L2) dengan nilai angka lempeng total $4,4 \times 10^{3} \mathrm{CFU} / \mathrm{g}$ pada hari ke-0 dan $4,7 \times 10^{4} \mathrm{CFU} / \mathrm{g}$ pada hari ke- 6 , kadar air di bawah $60 \%$ selama penyimpanan dan sifat organoleptik berupa skor aroma 4,48 (netral) dan skor penerimaan keseluruhan 4,51 (netral).

\section{DAFTAR PUSTAKA}

Achmadi SS, Mubarik NR, Nursyamsi R, Septiaji P. 2013. Characterization of redistilled liquid smoke of oil-palm shells and its application as fish preservatives. Joumal of Applied Sciences. 13(3):401-408. 
Bortolomeazzi R, Sebastianutto N, Toniolo R, Pizzariello A. 2007. Comparative evaluation of the antioxidant capacity of smoke flavouring phenols bycrocin bleaching inhibition, DPPH radical scavenging and oxidation potential. Food Chemistry.100: 1481-1489.

Boerhendhy I, Shinta DA. 2006. Potensi pemanfaatankayukaretuntukmendukung peremajaan perkebunan karet rakyat. Jurnal Litbang Pertanian.25(2):61-67.

[BPS]Badan Pusat Statistik. 2013. Survei Sosial Ekonomi Nasional. 2013. Jakarta (ID): Badan Pusat Statistik.

BraithwaiteM,VanVuurenSF,ViljoenAM.2008. Validation of smoke inhalation therapy totreat microbial infections. Journal of Ethnopharmacology.119:501-506.

Budijanto S, Hasbullah R, Prabawati S, Setyadjit, Sukarno, Zuraida I. 2008. Identification and safety test on liquidsmoke made from coconut shell forfood product Indonesian. Journal of Agricultural Postharvest Research. 5(1): 32-40.

Cardinal M J, Cornet T, Sérot R, Baron. 2006. Effects of the smoking process on odour characteristics of smoked herring (Clupea harengus) and relationships with phenolic compound content. Food Chemistry. 96(1):137-146.

De Fretes M T, Gunaedi SB, Surbakti. 2015. Bakteri proteolitik pada ikan tongkol (Euthynnus affinis) hasil proses pengasapan tradisional dan modern. Journal Biologi Papua. 7(1):1-8.

Desniar,Poernomo D, Wijatur W. 2009. Pengaruh Konsentrasi Garam pada Peda Ikan Kembung (Rastrelliger sp.) dengan Fermentasi Spontan. Jurnal Pengolahan Hasil Perikanan Indonesia. 12(1):73-87

Dwiyitno, Riyanto R. 2006. Studi Penggunaan Asap Cair untuk Pengawetan Ikan Kembung (Astrelliger negglectus) Segar. Jurnal Pasca Panen dan Bioteknologi Kelautan dan Perikanan.1(2): 143148.

Effendie Y. 2002. Biologi Perikanan. Padang (ID): Yayasan Pustaka Nusatama.

Esekhiagbe M, Agatemor MMU, Agatemor C. 2009. Phenolic contentandanti microbial potentials of Xylopia aethiopicaand
Myristicaargentea. Macedonian. Journal of Chemistry and Chemical Engineering. 28:159-162.

Gomez-Estaca J, Montero P, Gimenez B, Gomez-Guillen MC. 2007. Effect of functional edible films and highpressure processingon microbialand oxidative spoilage in cold-smoked sardine (Sardina pilchardus). Food Chemistry.105:511-520.

Guillén MD, Manzanos MJ. 2002. Study of the volatile composition of an aqueous oak smoke preparation. Food Chemistry.79: 283-292.

Hadiwiyoto S, Darmaji P, Purwasari SR. 2000. Perbandingan pengasapan panas dan penggunaan asap cair pada pengolahan ikan: tinjauan kandungan benzopiren, fenol dan sifat organoleptik ikan asap. Jurnal Agritech. 20(1):14-19.

HattulaT, Elfving K, Mroueh UM, Luoma T. 2001.Use of liquid smoke flavoring asan alternative to traditional fluegas smoking of rainbow trout fillets (Oncorhyncus mykiss). Lebensmittel Wissenschaft und Technologie. 34:521-525.

Himawati E. 2010. Pengaruh penambahan asap cair tempurung kelapa destilasi dan redestilasi terhadap sifat kimia, mikrobiologi dan sensoris ikan pindang layang (Decapterus spp) selama Penyimpanan. [skripsi]. Surakarta (ID): Universitas Sebelas Maret.

Husni A, Brats AK, Budhiyanti SA. 2015. Peningkatan daya simpan ikan kembung dengan ekstrak etanolik Padina sp. selama penyimpanan suhu kamar. Jurnal Pengolahan Hasil Perikanan Indonesia. 18(1):1-10.

Jittinandana S, Kenney PB, Slider SD, Mazik P, Bebak-Williams J, Hankins JA. 2003. Effect of fish attributes and handling stress on quality of smoked arctic char fillets. Journal of Food Science. 68: 57-63.

Kartika, Bambang. 1998. Pedoman Uji Inderawi Bahan Pangan. Yogyakarta (ID): Penerbit Pusat Antar Universitas Pangan dan Gizi.

Kolodziejska I, Niecikowska C, Januszewska E, SikorskiZE. 2002. Themicrobialandsensory quality of mackerel hot smoked in mild 
conditions. Lebensmittel Wissenschaftund Technologie. 35:87- 92.

Kristinsson HG, Danyali N, Ua-Angkoon S. 2007. Effect of filtered wood smoke treatment on chemical and microbial changes in mahi-mahi fillets.Journal of Food Science. 72: 16-24.

Leroi, Joffraud JJ. 2000. Salt and smoke simultaneously effect chemical and sensory quality of cold-smoked salmon during $5^{\circ}$ Cstorage predicted using factorial design. Journal of Food Protection. 63: 1222-1227.

Lestari YI, Idawati N, Harlina. 2015. Aktivitas antibakteri asap cair tandan kosong sawit grade 2 yang sebelumnya diadsorspi zeolit teraktivasi. JKK. 4(4):1-11.

Karseno, Darmaji P; Rahayu K. 2010. Daya hambat asap cair kayu karet terhadap bakteri pengkontaminan lateks dan ribbed smoked sheet. Jurnal Agritech. 21(1): 10-15

Milly PJ, Toledo RT, Ramakrishnan S. 2005. Determination of minimum inhibitory concentrations of liquid smoke fractions. Journal of Food Science. 70: 12-17.

MonteroP, Gomez-Guillen MC, Borderias AJ. 2003. Influence of salmon provenance and smoking process on muscle functional characteristics. Journal of Food Science 68: 1155-1160.

Muratore G, Licciardello F. 2005. Effect of vacuum and modified atmosphere packaging on the shelf-life ofliquidsmokeds word fish (Xiphiasgladius) slices. Journal of Food Science. 70:359-363.

Nur M. 2009. Pengaruh cara pengemasan, jenis bahan pengemas, dan lama penyimpanan terhadap sifat kimia, mikrobiologi dan organoleptik sate bandeng (Chanos chanos). Jurnal Teknologi dan Industri Hasil Pertanian. 14(1):1-11.

Panagan AT,Syarif N. 2009. Uji daya hambat asap cair hasil pirolisis kayu pelawan (Tristania abavata) terhadap bakteri Escherichia coli. Jurnal Penelitian Sains. 6:30-32.

Rahayu W P, Maamoen S, Suliantari, Fardiaz S. 1992. Teknologi Fermentasi Produk Perikanan. Bogor (ID): Penerbit Pusat
Antar Universitas Pangan dan Gizi, Institut Pertanian Bogor.

Rorvik LM. 2000. Listeria monocytogenes in the smoked salmon industry. International Journal of Food Microbiology. 62:183-190.

Saravanakumar A, Venkateshwaran K, Vanitha J, Ganesh M, Vasudevan M, Sivakumar T. 2009. Evaluation of antibacterial activity, phenol and flavnoid contentsof The spesia populnae flower extracts Pak. Journal of Pharmaceutical Sciences. 22:282-286.

Sari RN, Utomo BSB, Widianto TN. 2006. Engineering equipment manufacturer liquid smoke forsmoke fish production. Jurnal Pascapanen dan Bioteknologi Kelautan dan Perikanan. 1(1):65-73.

Satyajaya W. Suroso E, Al Rasyid H, Utomo TP. 2016. Kajian penentuan komoditas unggulan dalam pengembangan teknologi agroindustri rakyat di Kabupaten Tulang Bawang. Jurnal Kelitbangan. 4(01):22-36. Sengul M, Yildiz H, Gungor N, Cetin B, Eser Z,Ercisli S. 2009. Total phenolic content, antioxidant and antimicrobial activities of some medicinal plants. Pak. Journal Pharmaceutical Science.s 22:102-106.

Setha B. 2011. Pengaruh penggunaan asap cair terhadap kualitas fillet ikan cakalang asap. Logika. 9(1):28-37.

[BSN]BadanStandardisasiNasional.2006. Standard quality of smoked fish. SNI 2332.3:2015. Jakarta (ID): Badan Standardisasi Nasional.

[BSN]BadanStandardisasiNasional.2009. Ikan asap - Bagian 1: Spesifikasi. SNI 2725:1:2009. Jakarta (ID): Badan Standardisasi Nasional.

[BSN]BadanStandardisasiNasional.20015. Cara uji mikrobiologi- Bagian 3: Penentuan angka lempeng total (ALT) pada produk perikanan. Jakarta (ID): Badan Standardisasi Nasional.

Simon R, de la Calle B, Palme S, Meier D, Anklam E. 2005. Composition and analysis of liquid smoke flavoring primary products. Journal of Separation Science. 28:871-882.

Soldera S,Sebastianutto N, Bortolomeazzi R.2008. Composition of phenolic compounds and antioxidant activity of 
commercial aqueous smoke flavorings. Journal of Agriculture and Food Chemistry. 56: 2727- 2734.

Siregar RR. 2011. Pengolahan Ikan Kembung. Jakarta (ID): Pusat Penyuluhan Kelautan dan Perikanan.

Stolyhwo A, Sikorski ZE. 2005. Polycyclicaromatichydrocarbons in smoked fish- a critical review. Journal Food Chemistry.91:303-311.

Stohr V, Joffraud JJ, Cardinal M, Leroi F. 2001. Spoilage potential and sensory profile associated with bacteria isolated from cold smoked salmon. Food Research International 34:797-806.

Sulistijowati R, Djunaedi O, Nurhajati J, Afrianto E, Udin Z. 2011. Mekanisme Pengasapan. Bandung (ID): Percetakan Universitas Padjadjaran.

Sunen E, Fernandez-GalianB, Aristimuno C. 2001. Antibacterial activity of smoke wood condensates againts Aeromonas hydrophila, Yersinia enterolitica and Listeria monocytogenes at low temperature. Food Microbiology. 18: 387393.

SunenE,Aristimuno C, Fernandez-GalianB. 2003. Activityofsmokewoodcondensates against Aeromonas hydrophila and Listeria monocytogenesin vacuum-packed,coldsmoked rainbow trout storedat $4^{\circ} \mathrm{C}$. Food Research International. 36: 111-116.

Suroso E, Satyajaya W, Utomo TP, Julianti L. 2017. Financial feasibility study of liquid smoke industry from palm oil empty fruit bunch in Mesuji Regency, Lampung Province. Journal International Series on Interdisciplinary Science and Technology.1(2):23-36.

Swastawati F, Susanto R, Cahyono B, Trilaksono WA. 2012. Sensory evaluation and chemical characteristics of smoked stingray (dasyatis blekeery) processed by using two different liquid smoke. International Journal of Bioscience, Biochemistry and Bioinformatics.2(3): 212-216.

Towaha J, Aunillah A, Purwanto EH. 2013. Pemanfaatan asap cair kayukaret dan tempurung kelapa untuk penanganan polusi udara pada lump. Buletin Riset Tanaman Rempah dan Aneka Tanaman Industri.4(1):71-80.

Utomo T. 2014. Pengaruh rasio asap cair teks:lateks terhadap parameter fisik bokar. [skripsi]. Bandar Lampung (ID): Universitas Lampung.

Vitt SM, Himelbloom BH,CrapoCA. 2001. Inhibition of Listeria inocula and Listeria monocytogenes in a laboratory medium and cold- smoked salmon containing liquid smoke. Journal of Food Safety. 2: 111-125.

Waluyo L. 2007. Mikrobiologi Umum. Malang (ID): UMM Press.

Winarno FG. 2004. Kimia Pangan dan Gizi. Jakarta (ID): PT Gramedia Pustaka Utama.

Yanti AR, Rochima E. 2009. Pengaruh suhu pengeringan terhadap karakteristik kimiawi fillet lele dumbo asap cair pada penyimpanan suhu ruang. Jurnal Bionatura. 11(1):21-36.

[AOAC] Association of Analytical Chemist Publisher. 2005. Official methods of analysis of the association of official analytical chemist. Arlington Virginia USA: The Association of Official Analytical Chemist, Inc. Mayland. USA.

[AOAC] Association of Analytical Chemist Publisher. 2007. Official methods of analysis of the association of official analytical chemist. Arlington Virginia USA: The Association of Official 